\author{
WikTOR HALECKI, TOMASZ STACHURA \\ Uniwersytet Rolniczy im. Hugona Kołłątaja w Krakowie \\ Wydział Inżynierii Srodowiska i Geodezji \\ Katedra Melioracji i Kształtowania Środowiska \\ al. Mickiewicza 24/28, 30-059 Kraków \\ E-mail:w.halecki@ur.krakow.pl \\ t.stachura@ur.krakow.pl
}

\title{
STRUKTURA UŻYTKOWANIA TERENU ZLEWNI W OBSZARZE MIEJSKIM I WIEJSKIM, A UTRZYMANIE DOBREGO STANU CIEKÓW WÓD POWIERZCHNIOWYCH
}

\section{JAKOŚĆ WÓD POWIERZCHNIOWYCH}

Wpływ użytkowania zlewni na jakość wód powierzchownych wg RAMOWEJ DYREKTYWY WODNEJ (2000) przedstawia się za pomoca wskaźników biologicznych, których uzupełnieniem sa cechy hydromorfologiczne (m.in. kształt koryta cieku) i ocena parametrów fizykochemicznych, szczególnie stężenia azotanów i fosforanów (WILK i współaut. 2019). Zła jakość wody na terenach zurbanizowanych zwiazana jest $z$ duża ilościa utwardzonych powierzchni nieprzepuszczalnych, które jeżeli przekraczaja 5-10\% powierzchni całej zlewni, powoduja już znaczne pogorszenie stanu ekologicznego cieku (SCHIFF i BENOIT 2007). Dodatkowym czynnikiem potęgujacym zanieczyszczanie wód jest migracja ludności do miast generująca zwiększony pobór wody (MOURI i współaut. 2011), a w konsekwencji większa produkcję ścieków bytowych (CHMIELOWSKI i współaut. 2018). Ma to miejsce nawet wtedy, gdy w zlewni znajduja się czynne, ale nie w pełni sprawne oczyszczalnie ścieków (KANOWNIK i RAJDA 2008). Stwierdzono, że najniższe wartości badanych wskaźników notowano w cieku, który był zasilany ściekami $z$ gospodarstw domowych i dodatkowo wystapił do niego wyciek oleju. Nieznacznie lepsze stężenia obserwowano w cieku zanieczyszczanym „tylko” ściekami bytowymi (COUCEIRO i współaut. 2006). Badając jakość wody na terenach zurbanizowanych stwierdzono wzrost zanieczyszczenia wody płynącej (KowALIK i współaut. 2014).
Stopniowy wzrost zanieczyszczenia wód potoku nastapił, gdy jego trasa przebiegała przez obszary o rosnacej antropopresji: w kolejności tereny wiejskie, podmiejskie-osadnicze i zurbanizowane (PRZYDATEK i KANOWNIK 2019). Położenie geograficzne obiektów może powodować, że negatywny wpływ działalności człowieka na jakość wody nie jest wszędzie taki sam. Porównując zlewnie o podobnej antropopresji w dwóch różnych regionach USA wykazano, że relatywnie większa biotyczna wrażliwość i, w konsekwencji, zmiana parametrów fizykochemicznych wody występowała na Płaskowyżu Piedmont w porównaniu ze środkowym wybrzeżem Atlantyku (UTz i HiLderbRAND 2011). Stąd też heterogeniczność regionów jest bardzo ważnym czynnikiem wpływającym na jakość wody.

Zanieczyszczenia atmosferyczne w kształtowaniu jakości wód lądowych były przez długi czas niedoceniane. Działalność człowieka powoduje, że do atmosfery przedostaja się różnorodne zanieczyszczenia. Tam następuje ich rozpraszanie, transport oraz zachodza zmiany składu chemicznego, w wyniku czego często tworza się związki bardziej agresywne pod względem chemicznym. Destrukcyjna rolę zanieczyszczeń atmosferycznych na ekosystemy wodne uświadomiono sobie wraz $z$ narastającym zakwaszeniem opadów (CHEŁMICKI 2001). Występowanie składników fizykochemicznych w wodach opadowych zależy głownie od terenu i warunków, gdzie tworza się chmury, a także od późniejszego przemieszczania się mas powietrza i zacho-

Słowa kluczowe: inżynieria sanitarna, jakość wody powierzchniowej, gospodarka wodna, użytkowanie terenu, wskaźniki biologiczne 
dzacych w nich reakcjach chemicznych (JAСОВ i współaut. 2003). Dlatego jakość wód opadowych w dużej mierze powiazana jest $z$ funkcjonowaniem dużych zakładów przemysłowych. Porównujac stężenia jonów $\mathrm{NH}^{+}$,

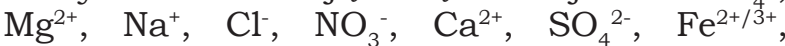
$\mathrm{Mn}^{2+}$, przed i po zamknięciu dużego zakładu przemysłowego produkującego stal stwierdzono, że gdy huta zaprzestała działanie, jakość wód opadowych znacznie się poprawiła (Miler i współaut. 2000). Ponadto, badania wpływu emisji substancj pochodzenia antropogenicznego na skład chemiczny opadu atmosferycznego w północno-wschodnich Chinach wykazały, że obszary przemysłowe miały istotny wpływ na wartość pH, które wskazywało na zakwaszenie wód; notowano także duże stężenia $\mathrm{SO}_{4}{ }^{2-}, \mathrm{Ca}^{2+} \mathrm{i} \mathrm{NH}_{4}^{+}$. Dodatkowo, odnotowano wysokie wartości $\mathrm{NH}_{4}^{+}$ $\mathrm{w}$ opadzie pochodzacym $\mathrm{z}$ mas powietrza w centralnych Chinach, gdzie prowadzone jest intensywne rolnictwo (WANG i wspólaut. 2008). Mokry i suchy opad zanieczyszczeń atmosferycznych stanowi łaczny ladunek substancji chemicznych, jaki wnoszony jest na obszar zlewni $z$ atmosfery. Większe znaczenie ma opad mokry, ponieważ zawiera on substancje chemiczne już rozpuszczone, majace przez to zdolność do szybkiej migracji $z$ powierzchni zlewni do wód gruntowych i powierzchniowych. Ponadto wody opadowe rozpuszczaja $i$ zmywaja $z$ powierzchni roślin składniki zdeponowane na nich $\mathrm{w}$ formie opadu suchego (OsTROWSKI i współaut. 2000). Największe szkody powoduja kwaśne deszcze obserwowane głównie na obszarach silnie uprzemysłowionych. Emitowane tam szkodliwe gazy dostaja sie do atmosfery i w wyniku licznych reakcji obniżaja $\mathrm{pH}$ wody opadowej, która w zetknięciu $\mathrm{z}$ powierzchnia wywołuje uszkodzenia i degradacje obszarów leśnych, niekorzystnie oddziałuje na organizmy żywe, w tym również na ludzi, nie jest też obojętna dla przyrody nieożywionej (YI i współaut. 2010). Zaobserwowano również, że wraz $z$ opadem do powierzchni gruntu przenoszone sa znaczne ladunki składników eutrofizujących, wykazujących ponadto zróżnicowanie przestrzenne i czasowe (RAJDA i współaut. 1995, HALECKI i współaut. 2016).

Zapewnienie odpowiedniej ilości i jakości wody w Polsce wymaga działań zmierzajacych do zwiększenia dostępności jej użytecznych zasobów; dotyczy to również innych krajów europejskich (KANOwNIK i współaut. 2019). Badania jakości wody sa jednak konieczne, ponieważ zlewnie szczególnie małych cieków, narażone sa na wpływy antropogeniczne związane $z$ działalnościa rolnicza, osadnictwem, transportem oraz innymi przedsięwzięciami, powodujacymi zanieczyszczenie wody (HALECKI 2015).
Retencja i zagospodarowanie odpływu wody sa głównymi celami polskich programów mikro-, małej i makro-retencji (OstrowsKi i współaut. 2005). Działania te zwiększaja bezpieczeństwo przeciwpowodziowe (obniżenie wielkości fal wezbraniowych), poprawiaja zdolności do zatrzymywania wód opadowych i usprawniaja ochronę wód powierzchniowych przed zanieczyszczeniem oraz wydłużaja czasu obiegu wody. Wpływają również na podwyższania poziomu wód gruntowych i zwiększenie zasilania warstw wodonośnych, przez co również na bilans wodny zasobów wód podziemnych (KANOwNIK i współaut. 2011).

\section{UŻYTKOWANIE I ZAGOSPODAROWANIE TERENU ZLEWNI}

Użytkowanie terenów zlokalizowanych najbliżej cieków wodnych najbardziej kształtuje jakość wód powierzchniowych (HALECKI i współaut. 2019). Ocena stanu ekologicznego wód płynących jest bardzo ważna ze względu na implementowanie prawa przez kraje Unii Europejskiej (ROZPORZĄDZENIE RADY MINISTRÓw 2018). Dyrektywa Azotanowa, dotycząca ochrony wód przed zanieczyszczeniami powodowanymi przez azotany pochodzenia rolniczego i Ramowa Dyrektywa Wodna, stanowiace unijne regulacje prawne sa obecnie w Polsce wprowadzone przez ustawę Prawo Wodne (UstaWA 2017). Bardzo istotne jest, aby zapewnienie odpowiedniej ilości wody szło $\mathrm{w}$ parze $\mathrm{z}$ jej właściwa jakościa, ponieważ zanieczyszczone wody nie pozwola na pełne wykorzystanie zbiorników wodnych, a przy ich bardzo złej jakości, moga w krótkim czasie doprowadzić do degradacji zbiornika (HALECKI 2019). Spełnienie większości wymagań może mieć pozytywne skutki w postaci utworzenia parków rzecznych, które np. w mieście pełnia funkcje rekreacyjno-przyrodnicze (HALECKI 2017). Na terenach rolnych małych zlewni zasolenie, wilgotności, zawartość iłu, gęstość objętościowa i temperatura gleby, maja decydujacy wpływ na jej właściwości (HALECKI i współaut. 2017).

Do badań jakości wody wykorzystuje się rożne metody. Należą do nich: symulacje/ modelowanie za pomoca oprogramowania (HALECKI i współaut. 2018a, b, c), metody predykcyjne przy użyciu zaawansowanych technik regresyjnych (HALECKI i współaut. 2019) oraz ocena przepływu środowiskowego, będącego wyznacznikiem stanu ekologicznego (MA i współaut. 2018). Wszystkie omówione wcześniej badania maja na celu ukazanie zdolności wody do samooczyszczania, co jest ważne przy pracach rewitalizacyjnych. Wówczas w dużej mierze możliwe będzie utrzymanie stanu siedliska przyrodni- 
czego na zadowalającym dla ludzi poziomie (KLARZYŃSKA i współaut. 2015). Warto nadmienić, że w obszarze miejskim kontrola i monitoring przyczyniają się do właściwego zagospodarowania terenu (KALETA i wspólaut. 2019), jako fragmentu tzw. infrastruktury błękitno-zielonej, czyli rozwoju sieci terenów zielonych nad brzegiem wód powierzchniowych (Bedla i wspólaut. dane nieopublikowane).

\section{WARTOŚCI WSKAŹNIKA \\ BIOLOGICZNEGO JAKOŚCI WÓD POWIERZCHNIOWYCH}

Okrzemki bentosowe pozwalaja na ocene jakości wody, ponieważ konkretne gatunki żyja tylko w określonych warunkach i ich obecność w danym cieku jest silnie skorelowana $z$ niektórymi wskaźnikami fizykochemicznymi wody. Dzieje się tak, gdyż okrzemki mają zróżnicowana tolerancję ekologiczna, a niektóre $z$ nich moga bytować nawet $\mathrm{w}$ bardzo zanieczyszczonych wodach (VAN DAM i współaut. 1994). Dzięki referencyjności okrzemek, już na podstawie ich występowania, bez konieczności oznaczeń wskaźników fizykochemicznych, jesteśmy w stanie określić jakość biologiczna wody. W praktyce do tego celu służą liczne wskaźniki okrzemkowe, $z$ których w Europie stosowanych jest około 20 (PRYGIEL i współaut. 1999). Indeksy okrzemkowe w ilościowy sposób przedstawiają określony (w zależności od zastosowanego wskaźnika) parametr fizykochemiczny jakości wody, stan ekologiczny danego cieku lub zbiornika, czy też jego trofię lub saprobię (zanieczyszczenie organiczne) (KwADRANS i współaut. 1998), przez co pozwalaja na porównania $z$ innymi obiektami zbadanymi tymi samymi metodami.

\section{WSKAŹNIKI OKRZEMKOWE W OCENIE STANU EKOLOGICZNEGO WOOD PŁYNĄCYCH}

Jakość wody w cieku determinowana jest przez lokalizacje zlewni względem dużych aglomeracji miejskich oraz zwiazany $z$ tym sposób ich zagospodarowania i użytkowania. Przykładowo, rzeźba terenu w Małopolsce sprzyja odpływowi wody, przez co potrzeba zwiększenia sztucznej retencji jest wyjątkowo uzasadniona. Porównano wartości wskaźników okrzemkowych w cieku Osielczyk, położonym $\mathrm{z}$ daleka od ośródka miejskiego, w cieku Rygliczanka, zlokalizowanej w pobliżu strefy zamieszkałej oraz w cieku Sudół Dominikański, usytuowanym w Krakowie. Przeprowadzono oznaczenia gatunków okrzemek, które występowały w analizowanych ciekach. Poboru prób dokonano jesienia, przy niskim stanie wód, stosujac metodyke opracowana przez PicińsKA-FAŁTYNOWICZ i BŁACHUTA (2010). Do oceny jakości i stanu ekologicznego wody wykorzystano indeks okrzemkowy IO, zaproponowany przez PICIŃSKA-FAeTYNOWICZ (2009). Wskaźnik ten bazuje na niemieckiej metodzie opracowanej przez SCHAUMBURG i współaut. (2005), która została dostosowana do polskich warunków. IO składa się $z$ trzech modułów: trofii TI (ROTT i współaut. 1999; zmodyfikowany) określajacej żyzność wód na podstawie równania (1); saprobii SI (ROTT i współaut. 1997; zmodyfikowany) wskazujacej poziom zanieczyszczeń organicznych wód, wyznaczany $z$ równania (2) oraz modułu gatunków referencyjnych GR (SCHAUMBURG i współaut. 2006), wyliczony $z$ równania (3):

$$
\mathrm{TI}=\frac{\sum \mathrm{T}_{\mathrm{i}} \times \mathrm{w} \mathrm{T}_{\mathrm{i}} \times \mathrm{L}_{\mathrm{i}}}{\sum \mathrm{w} \mathrm{T}_{\mathrm{i}} \times \mathrm{L}_{\mathrm{i}}}
$$

gdzie:

$\mathrm{T}_{i}$ - wartość wrażliwości na stan troficzny i-tego taksonu;

$\mathrm{wT}_{\mathrm{i}}$ - wartość wagowa (zakres tolerancji) i-tego taksonu;

$\mathrm{L}_{\mathrm{i}}$ - względna obfitość i-tego taksonu (liczba osobników i-tego taksonu podzielona przez liczbę wszystkich zliczonych osobników).

$$
\mathrm{SI}=\frac{\sum \mathrm{S}_{\mathrm{i}} \times \mathrm{w} \mathrm{S}_{\mathrm{i}} \times \mathrm{L}_{\mathrm{i}}}{\sum \mathrm{w} \mathrm{S}_{\mathrm{i}} \times \mathrm{L}_{\mathrm{i}}}
$$

gdzie:

$\mathrm{S}_{\mathrm{i}}$ - wartość wrażliwości i-tego taksonu na zanieczyszczenia organiczne;

$\mathrm{wS}_{\mathrm{i}}$ - wartość wagowa (zakres tolerancji) i-tego taksonu;

$\mathrm{L}_{\mathrm{i}}$ - względna obfitość i-tego taksonu (liczba osobników i-tego taksonu podzielona przez liczbę wszystkich zliczonych osobników).

$$
\mathrm{GR}=\sum t R i
$$

gdzie:

$\mathrm{tR}_{\mathrm{i}}$ - względna liczebność i-tego taksonu referencyjnego (liczba osobników i-tego tak-

Tabela 1. Graniczne wartości wskaźnika IO (wg PiciŃSKA-FAŁTYNOWICZ i BŁACHUTA 2010).

\begin{tabular}{ll}
\hline Stan ekologiczny & Wartość IO \\
\hline Bardzo dobry & $>0,70$ \\
Dobry & 0,50 \\
Umiarkowany & 0,30 \\
Zły & 0,15 \\
Bardzo zły & $<0,15$ \\
\hline
\end{tabular}


Tabela 2. Zakres zmienności modułów okrzemkowych (wg PicińSKA-FAŁTYNOwiCz i BŁACHUTA 2010).

\begin{tabular}{llll}
\hline Moduly & Oznaczenie & Zakres zmienności & Objaśnienie \\
\hline Trofii & TI & $0-4$ & 0 - wartość najkorzystniejsza \\
& SI & $1-4$ & 4 - wartość najmniej korzystna \\
Saprobii & & 1 - wartość najkorzystniejsza \\
& GR & $0-1$ & 4 - wartość najmniej korzystna \\
$\begin{array}{l}\text { Gatunków } \\
\text { referencyjnych }\end{array}$ & & 0 - żaden z taksonów w próbie nie jest referencyjny \\
& & $1-$ wszystkie taksony w próbie sa referencyjne \\
\hline
\end{tabular}

Tabela 3. Zestawienie modułów wskaźników okrzemkowych $z$ oceną statusu ekologicznego.

\begin{tabular}{lllllll}
\hline Ciek & Mezoregion wg KondRACKI (2009) & TI & SI & GR & IO & Status ekologiczny \\
\hline Osielczyk & Beskid Makowski & 1,82 & 1,60 & 0,88 & 0,74 & Bardzo dobry \\
Rygliczanka & Pogórze Ciężkowickie & 3,25 & 2,15 & 0,28 & 0,36 & Umiarkowany \\
Sudół Dominikański & Płaskowyż Proszowicki & 3,07 & 2,24 & 0,34 & 0,39 & Umiarkowany \\
& & & & & & \\
\hline
\end{tabular}

sonu referencyjnego podzielona przez liczbę wszystkich zliczonych osobników).

Moduł GR obliczany jest w oparciu o taksony referencyjne podzielone na 3 grupy okrzemek, w zależności od występowania w wodach: krzemianowych, węglanowych lub preferujacych oba typy wód.

Wyznaczono wartości graniczne wskaźnika IO poszczególnych klas stanu ekologicznego (Tabela 1).

Moduły TI, SI i GR maja różne przedziały zmienności (Tabela 2), dlatego dla obliczenia multimetrycznego wskaźnika okrzemkowego IO należy je sprowadzić do identycznego zakresu możliwych wartości. W tym celu wyliczono znormalizowane wskaźniki $Z_{\mathrm{TI}}$ i $Z_{\mathrm{SI}}$ (wzory 4 i 5) według metody opublikowanej przez SchAUMBURG i współaut. (2006). Wskaźnika GR nie przelicza się, ponieważ jego wartości zmieniaja się w przedziale (01), który jest docelowym zakresem indeksu IO.

$$
Z_{\mathrm{TI}}=1-0,25 \mathrm{TI}
$$

gdzie: trofii;

$Z_{\text {ТI }}$ - znormalizowana wartość wskaźnika

TI - Wartość ZTI zmienia się w przedziale od 1 (najkorzystniejszy) do 0 (najmniej korzystny).

$Z_{\mathrm{SI}}=1-0,33(\mathrm{SI}-1)$

gdzie:

$\mathrm{Z}_{\mathrm{SI}}$ - znormalizowana wartość wskaźnika saprobii;
SI - Wartość ZSI zmienia się w przedziale od 1 (najkorzystniejszy) do 0 (najmniej korzystny). (6):

Ostatecznie IO oblicza się według wzoru

$$
\mathrm{IO}=\frac{\mathrm{z}_{\mathrm{TI}}+\mathrm{z}_{\mathrm{SI}}+\mathrm{GR}}{3}
$$

Cieki Rygliczanka i Sudół Dominikański miały umiarkowany status ekologiczny. Osielczyk w Beskidzie Makowskim wykazał lepsze wartości modułu GR, przez co indeks IO, był również trochę korzystniejszy (Tabela 3 ).

W pobranej próbie $z$ potoku Osielczyk łącznie oznaczono 82 gatunki okrzemek bentosowych, gdzie dominującymi gatunkami (powyżej 5\% liczności próby) były: Achnanthidium biasolettianum (Ryc. 1) - 45\% udziału w próbie; Achnanthidium minutissimum - 25\% (Ryc. 2); Gomphonema olivaceum var. olivaceum (Ryc. 3) - 9\%. Tylko 7 oznaczonych gatunków nie było referencyjnych, ponieważ występowały pojedynczo. Status ekologiczny potoku został oceniony jako bardzo dobry (Tabela 1). Stało się to dzięki dobrym wartościom modułów: trofii, saprobii i gatunków referencyjnych (Tabela 2).

Gatunkami okrzemek dominujacymi w potoku Rygliczanka były: Navicula lanceolata - 25\%, Navicula gregaria - 19\%, Gomphonema tergestinum - 9\%, Achnanthidium pediculus - 7\% i Gomphonema olivaceum var. olivaceum (Ryc. 3) - 5\%. Stwierdzono rów- 


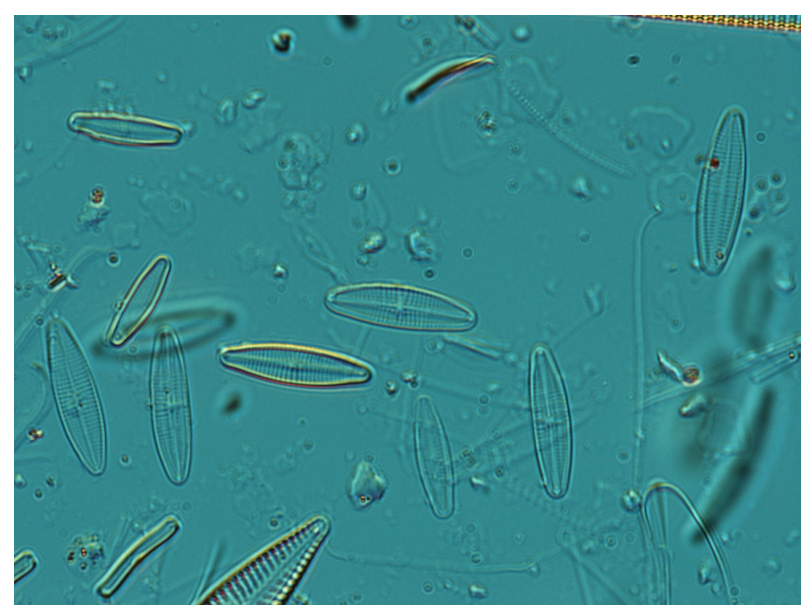

Ryc. 1. Achnanthidium biasolettianum, ciek Osielczyk (zdjęcie: Teresa Noga).

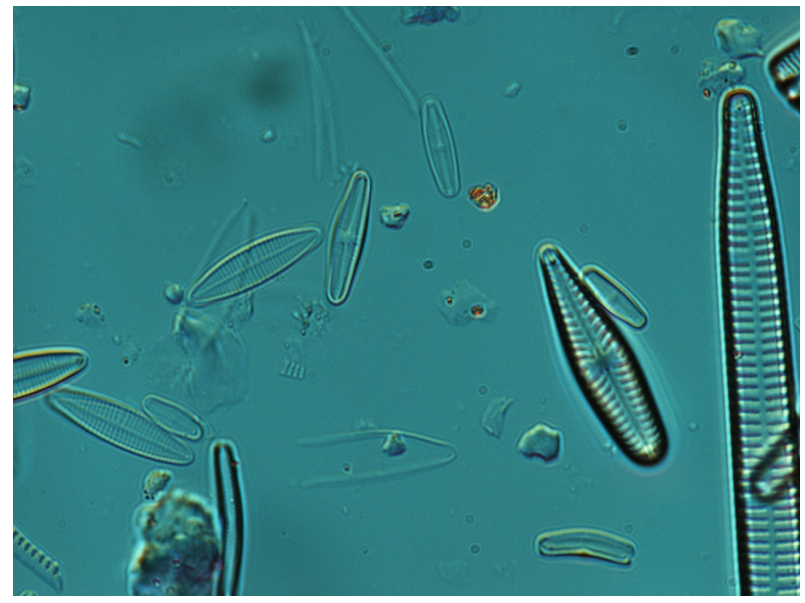

Ryc. 2. Achnanthidium minutissimum, ciek Osielczyk (zdjęcie: Teresa Noga).

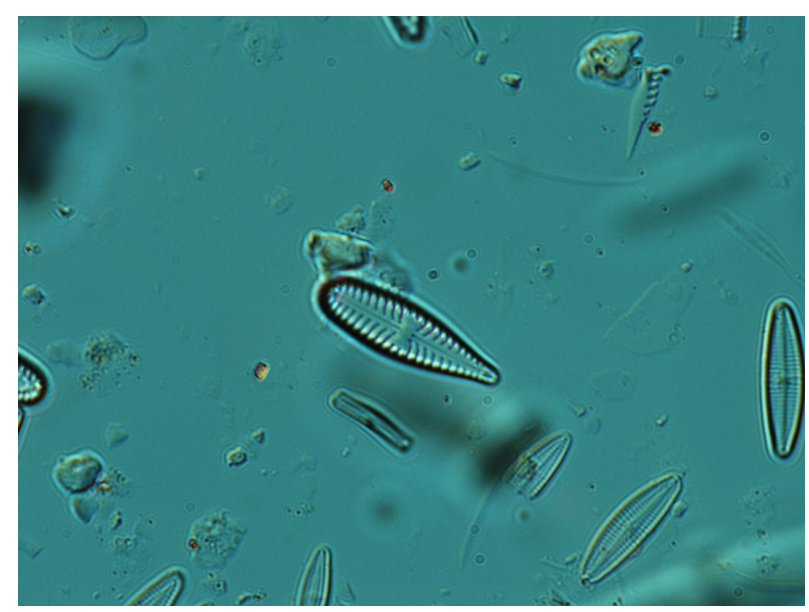

Ryc. 3. Gomphonema olivaceum var. Olivaceum, cieki Osielczyk i Rygliczanka (zdjęcie: Teresa Noga).

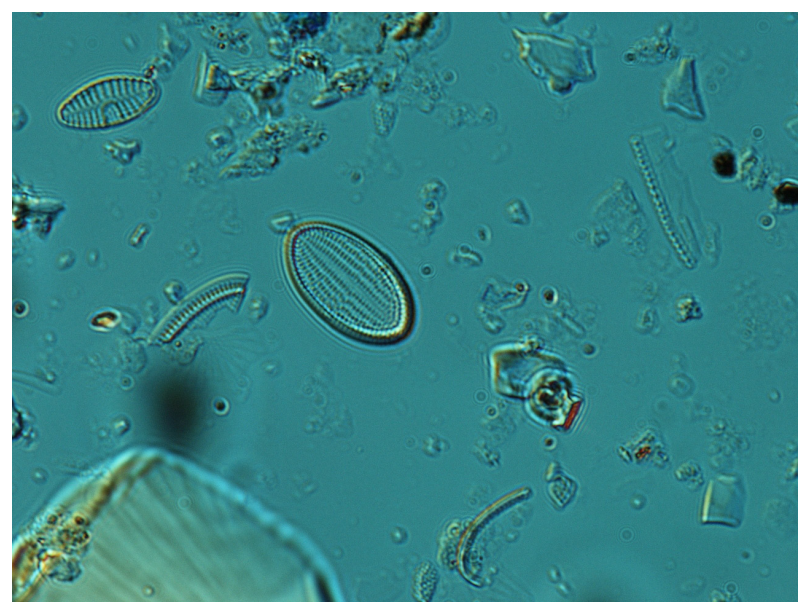

Ryc. 4. Cocconeis placentula var. Lineata, ciek Sudół Dominikański (zdjęcie: Teresa Noga).

nież występowanie 10 gatunków niereferencyjnych.

Sudół Dominikański charakteryzował się trzema dominujacymi gatunkami: Cocconeis placentula var. lineata (Ryc. 4) - 16\%, Navicula tripunctata - 13\% i Achnanthidium pediculus - 12\%. Ponadto stwierdzono obecność 19 gatunków niereferencyjnych, które sumarycznie stanowiły $7 \%$ badanej populacji.

\section{PODSUMOWANIE}

Zanieczyszczenie wody w większości powodowane jest przez aktywność człowieka, wobec czego musi on podejmować działania zapobiegające pogorszeniu jakości wody. Badania nad jakościa wód prowadzone sa przede wszystkim lokalnie na potrzeby społeczeństwa, jednak powinno się przeprowadzić kompleksowe badania obejmujące szeroki zakres prac zwiazanych $z$ problematyka inżynierii środowiska. Dużym problemem jest niska jakość wód powierzchniowych, ponieważ podlegaja one znacznym wpływom antropogenicznym, ograniczającym dostępność wody dobrej jakości. W ocenie jakości wód powierzchniowych należy uwzględnić metody $z$ wykorzystaniem biologicznych i fizykochemicznych indykatorow oraz hydromorfologię koryta. Następnie należy opracować charakterystyki zlewni, wykorzystujacc mapy użytkowania terenu.

Jednym ze sposobów rozwiazywania niełatwych problemów gospodarki wodnej moga być różnego rodzaju działania przyrodniczo-techniczne i organizacyjne, sprzyjajace gromadzeniu wody, opóźniające odpływ i zwiększające jej dostępność dla gospodarki, w tym dla produkcji rolniczej i kształtowania krajobrazu, określane ogólnie jako mikro-, mała i makro-retencja wodna. Retencja wody to poprawa walorów przyrodniczych i zwiększenie 
biologicznej różnorodności (tworzenie naturalnych enklaw dla zwierzat i roślin). Retencjonowanie wody ma również znaczenie ogólnospołeczne. Tworzenie tzw. infrastruktury błękitno-zielonej, spowoduje wzrost oraz pozyskanie środków zewnętrznych na realizację przedsięwzięć łagodzacych społeczne skutki bezrobocia i zwiększy atrakcyjność terenu (kapieliska i plaże rekreacyjne $z$ przyjaznym mikroklimatem).

\section{Streszczenie}

Dbanie o stan ekologiczny zasobów wodnych zarówno $\mathrm{w}$ mieście, jak na obszarach wiejskich jest problemem niezwykle ważnym i aktualnym. Celem artykułu jest przybliżenie bieżącej polityki środowiskowej dotyczacej oceny stanu cieków wód powierzchniowych. Jakość wody powierzchniowej zależy od sposobu zagospodarowania gleb oraz warunków meteorologicznych, które zmieniaja procesy glebowe. Niestety nie da się odseparować poszczególnych części i jednoznacznie określić, które $z$ nich wykazuja niekorzystny wpływ na jakość wody. Przykładowo, badania dotyczace wymywania składników pokarmowych $z$ gleb do wód powierzchniowych wymagaja wizyt terenowych podczas pracy monitorujaccej zarzadzanie gospodarka wodna. Ponadto, trudno jest ocenić ich bezpośrednie oddziaływanie na jakość wód powierzchniowych. Dlatego istnieje wiele zagrożeń w zarządzaniu zasobami wodnymi odnośnie ludzkiego zdrowia. W krajach Unii Europejskiej, w pierwszej kolejności ocenia się walory ekologiczne $\mathrm{w}$ zlewni, a następnie fizykochemiczne w cieku i hydromorfologiczne cechy koryta, które stanowia elementy wspierajace. W ocenie stanu sanitarnego najczęściej widoczny jest wpływ antropopresji. Ze względu na to, że dostępność wody i jej jakość ma kluczowe znaczenie w długoterminowej polityce środowiskowej i prawidłowym rozwoju społeczeństw, należy nadal poszerzać badania w tym zakresie.

\section{LITERATURA}

CHEŁMICKI W., 2001. Woda-zasoby, degradacja $i$ ochrona. PWN, Warszawa.

Chmielowski K., Dacewicz E., Bedla D., MAZUR R., 2018. Zastosowanie odpadów $z$ tworzyw sztucznych $w$ biofiltrach do oczyszczania ścieków bytowych. Przemysł Chemiczny 97, 1456-1459.

COUCEIRO S. R. M., Forsberg B. R., HAMADA N., FERREIRA R. L. M., 2006. Effects of an oil spill and dis charge of domestic sewage on the insect fauna of cururu stream, manaus, AM, Brazil. Brazilian J. Biol. 66, 35-44.

HALECKI W., 2015. Wskaźniki jakości gleb i wód powierzchniowych. Wszechświat 116, 267269.

HALECKI W., 2017. Parki rzeczne - jako forma ochrony powietrza $w$ Miejskiej Wyspie Ciepła. Wszechświat 118, 4-6.

HALECKI W., 2019. Erozja wodna - przyczyna odpływu zwiazków biogennych ze źródet rolniczych do cieków powierzchniowych. Aura Ochrona Środowiska 1, 6-11.

HALECKI W., MŁYŃSKI D., RYCZEK M., KRUK E., LIS J., 2016. Zmienność przestrzenna wilgotności $i$ gęstości objętościowej gleby $w$ zlewni potoku górskiego Mątny w Gorcach. Episteme 30, 347-358.

Halecki W., MŁYŃSKi D., RYczeK M., KRUK E., RADECKI-PAWLIK A., 2017. Applying an Artificial
Neural Network (ANN) to assess soil salinity and temperature variability in agricultural areas of a mountain catchment. Pol. J. Environ. Studies 6, 2545-2554.

HaleCKI W., KRUK E., RYCZEK M., 2018a. Estimations of nitrate nitrogen, total phosphorus flux and suspended sediment concentration (SSC) as indicators of surface-erosion processes using an ANN (Artificial Neural Network) based on geomorphological parameters in mountainous catchments. Ecol. Indicat. 91C, 461469.

HALECKI W., KRUK E., RYCZEK M., 2018b. Evaluation of water erosion at a mountain catchment in Poland using the G2 model. Catena 164, 116-124.

HALECKI W., KRUK E., RYCZEK M., 2018c. Loss of topsoil and soil erosion by water in agricultural areas: A multi-criteria approach for various land use scenarios in the Western Carpathians using a SWAT model. Land Use Policy $73,363-372$.

Halecki W., STAchuRa T., Fudąa W., Rusnak M., 2019. Evaluating the applicability of MESS (matrix exponential spatial specification) model to assess water quality using GIS technique in agricultural mountain catchment (Western Carpathian). Environ. Monitor. Assess. 191, 26.

JaCOB D. J., CRAWFORD J. H., KleB M. M., CONNORS V. S., BENDURA R. J., RAPER J. L., SACHSE G. W., GILle J. C., EMmONS L., HEALD C. L., 2003. Transport and chemical evolution over the pacific (TRACE-P) aircraft mission: design, execution, and first results. J. Geophys. Res. Atmospheres 108, 1-19.

Kaleta J. T., PUszkarewicz A., PAPCiaK D., 2019. The Influence of the city of Przemysil on the quality of water in the San river. J. Ecol. Engin. 20, 76-83.

KANOWNIK W., RAJDA W., 2008. Źródła zanieczyszczenia wód powierzchniowych $w$ zlewni potoku Sudół Dominikański. Acta Sci. Pol. Formatio Circumiectus 7, 3-14.

KANOWNIK W., KOWALIK T., BOGdAL A., OstrowsKI K., RAJDA W., 2011. Jakość $i$ walory użytkowe wody potoku Szczyrzawy. Zeszyty Problemowe Postępów Nauk Rolniczych 561, 65-79.

KanOWNIK W., POLICHT-LATAWIEC A., FUdAŁA W., 2019. Nutrient pollutants in surface water-assessing trends in drinking water resource quality for a regional city in central Europe. Sustainability 11, 1988

KLARZYŃSKA A., KRYSZAK A., KACZMAREK K., KRYSZAK J., MAĆKOWIAK Ł., 2015. Wpływ sposobu użytkowania terenu na różnorodność nadbrzeżnych zbiorowisk roślinnych $i$ stan wód rzeki Wirenki. Fragmenta Agronom. 32, 3950.

KONDRACKI J., 2009. Geografia regionalna polski. PWN, Warszawa.

KOWALIK T., KANOWNIK W., BOGDAE A., POLICHT-LATAWIEC A., 2014. Wpływ zmian użytkowania zlewni wyżynnej na kształtowanie jakości wody powierzchniowej. Rocznik Ochrona Srodowiska 16, 223-238.

KWADRANS J., ELORANTA P., KAWECKA B., WOJTAN K., 1998. Use of benthic diatom communities to evaluate water quality in rivers of southern Poland. J. Appl. Phycol. 10, 193-201.

MA L., ZHANG X., WANG H., QI C., 2018. Characteristics and practices of ecological flow in rivers with flow reductions due to water storage and hydropower projects in China. Water $10,1091$.

Miler A., Liberacki D., Plewiński D., 2000. Ilościowa $i$ jakościowa ocena odpływu $z$ 
dwu kontrastowych pod wzgledem zalesienia mikrozlewni nizinnych. Zeszyty Naukowe, AR Kraków 365, 435-444.

Mouri G., TAKIZAWA S., OKI T., 2011. Spatial and temporal variation in nutrient parameters in stream water in a rural-urban catchment, shikoku, Japan: Effects of land cover and human impact. J. Environ. Manage. 92, 1837-1848.

Ostrowski K., BOGDAE A., NATKANIEC J., 2000. Wybrane cechy fizykochemiczne wód opadowych. Zeszyty Naukowe, AR Kraków 370, Inżynieria Środowiska 20, 15-27.

OSTROWSKI K., BOGDAE A., RAJDA W., 2005. Wpływ użytkowania wybranych mikrozlewni Pogórza Wielickiego na zawartość $i$ sezonowa zmienność cech fizyko-chemicznych $w$ wodach odpływajacych Zeszyty Naukowe, AR Kraków 420, Inżynieria Środowiska 26, 9-19.

PiCIŃSKA-FAETYNOWICZ J., 2009. Diatom phytobenthos as a tool for assessing the ecological status of Polish rivers. Oceanol. Hydrobiol. Stud. Int. J. Oceanography Hydrobiol. 37 (Suppl. 2), p. 155-161.

PicińSKA-FAetynowicz J., BŁachuta J., 2010. Wytyczne metodyczne do przeprowadzenia oceny stanu ekologicznego jednolitych części wód rzek $i$ jezior oraz potencjału ekologicznego sztucznych $i$ silnie zmienionych jednolitych części wód płynacych Polski na podstawie badao fitobentosu. Zlecenie GIOŚ. IMGW. Wrocław, 1-79.

Prygiel J., Coste M., Bukowska J., 1999. Review of the major-based techniques for the quality assessment of rivers - State of the art of Europe. Use of Algae for Monitoring Rivers 3, 224-238.

PRZYDATEK G., KANOWNIK W., 2019. Impact of small municipal solid waste landfill on groundwater quality. Environ. Monitor. Assessment 1 a91, 169.

RAJDA W., Ostrowski K., KowaliK T., Marzec J., 1995. Stężenia $i$ ładunki niektórych składników chemicznych wnoszonych $z$ opadem $i$ odpływajacych $z$ mikrorozlewni rolniczej. Zeszyty Naukowe, AR Kraków 45, 45-57.

RAMOWA DYREKTYWA WODNA, 2000. Dyrektywa 2000/60/WE Parlamentu Europejskiego i Rady z 23 października 2000 r. ustanawiajaca ramy wspólnotowego działania $w$ dziedzinie polityki wodnej. Dziennik Urzędowy Wspólnot Europejskich 2000, L 327. 34.

RotT E., HofmanN G., Pall K., PFister P., PiPP E., 1997. Indikationslisten für ufwuchsalgen. Teil1. Saprobielle Indikation. Bundesministerium für Land- und Forstwirtschaft. Wien, Austria.
RotT E., Binder N., VAN DAm H., ORTLER K., PAll K., PFISTER P., PIPP E., 1999. Indikationslisten füraufwuchsalgen. Teil 2. Trophieindikation und autökologische anmerkungen, bundesministerium für land- und forstwirtschaft. Wien, $1-248$.

ROZPORZADZENIE RADY MINISTRÓw, 2018. Rozporzadzenie z 5 czerwca 2018 r. $w$ sprawie przyjęcia „Programu działan majacych na celu zmniejszenie zanieczyszczenia wód azotanami pochodzacymi ze źródeł rolniczych oraz zapobieganie dalszemu zanieczyszczeniu". Dziennik Ustaw 2018, poz. 1339.

UstawA, 2017. Ustawa z 20 lipca 2017 r. Prawo wodne. Dziennik Ustaw 2017, poz. 1566.

UTZ R. M., HILDERBRAND R. H., 2011. Interregional variation in urbanization-induced geomorphic change and macroinvertebrate habitat colonization in headwater streams. J. North Am. Benthol. Soc. 30, 25-37.

Schaumburg J., SchmedTJE U., Schranz Ch., KÖPF B., SCHNEIDER S., MEILINGER P., HOFMANN G., GUTOWSKI A., FOERSTER J., 2005. Instruction protocol for the ecological assessment of running waters for the implementation of the EU water framework directive: Macrophytes and phytobenthos. Bavarian Water Management Agency, München.

Schaumburg J., Schranz Ch., Stelzer D., HofMANN G., GUTOWSKI A., FOERSTER J., 2006. Instruction protocol for the ecological assessment of running waters for implementation of the EU water framework directive: Macrophytes and phytobenthos. Bavarian Water Management Agency, München.

SchifF R., BENOIT G., 2007. Effects of impervious cover at multiple spatial scales on coastal watershed streams. J. Am. Water Resources Assoc. 43, 712-730.

Van Dam H., Mertens A., Sinkeldam J., 1994. A coded checklist and ecological indicator values of freshwater diatoms from The Netherlands. Neth. J. Aquat. Ecol. 28, 117-133.

WANG Y., WAI K. M., GaO J., LIU X., WANG T., WANG W., 2008. The impacts of anthropogenic emissions on the precipitation chemistry at an elevated site in North-eastern China. Atmosph. Environ. 42, 2959-2970.

WilK P., ORLINSKA-WOZNIAK P., SZALINSKA E., 2019. Assessment of total nitrogen loads discharged from agricultural catchments in the context of changes in the nitrates directive implementation. Ochrona Środowiska 41, 1, 55-64.

Yi L., XiaOlan Y., HongBing Ch., Weili L., Jie T., SHUFENG W., 2010. Chemical characteristics of precipitation at three Chinese regional background stations from 2006 to 2007. Atmosph. Res. 96, 173-183. 
KOSMOS Vol. 69, 2, 373-380, 2020

\author{
WiKTOR HALECKI, TOMASZ STACHURA
}

University of Agriculture in Krakow, Faculty of Environmental Engineering and Land Surveying, epartment of Land Reclamation and Environmental Development, 24/28 Mickiewicza Av., 30-059 Kraków,E-mail:w.halecki@ur.krakow.pl, t.stachura@ur.krakow.pl

\title{
STRUCTURE OF USE OF THE CATCHMENT AREA IN URBAN AND RURAL AREA, AND MAINTAINING THE GOOD
} CONDITION OF SURFACE WATER

\section{Summary}

Caring for the ecological state of water resources both in the city and in rural areas is an extremely important and topical problem. The aim of the article is to present the current environmental policy regarding the assessment of surface watercourses. The quality of surface water depends both on the land management and the meteorological conditions that change soil processes. Unfortunately, it is impossible to separate individual contributions and clearly determine which of them have an adverse effect on water quality For example, research on the leaching of nutrients from soils into surface waters requires field visits during monitoring work on water management. Additionally, the evidence of their direct influence on the surface water quality has been difficult to assess. That is why there are many threats to the management of water resources regarding human health. In the European Union countries, ecological values in the catchment are assessed first, followed by physicochemical properties in the watercourse and hydromorphological features of the riverbed, which are supporting elements. Moreover, in assessing sanitation, the impact of anthropopressure is most often visible. Due to the fact that water availability and quality are of key importance in long-term environmental policy and the proper development of societies, research in this field should be continued and expanded.

Keywords: biological indicators, land use, sanitary engineering, surface water quality, water management 